\title{
Truancy and its Influence on Students' Learning in Dormaa Senior High School
}

\begin{tabular}{l|l|}
\hline Gyimah Henry' (iD \\
Daniel Yelkpieri'
\end{tabular}

\begin{abstract}
The study instigated the incidence of truancy among students and its influence on learning in the Dormaa Senior High School. A descriptive survey design was adopted in carrying out the study. The study population consisted of teachers, students, parents and opinion leaders in the study area. The simple random and purposive samplings were used in selecting respondents. A sample of 135, made up of 20 teachers and 100 students, 10 parents and 5 opinion leaders were selected to participate in the study. A set of questionnaires was designed and administered to the teachers and students. Documentary evidence from the class attendance register and students' report cards were used. In the case of the parents and opinion leaders, semi-structured interview schedules were developed and used to obtain their views. Descriptive statistics were used in presenting the quantitative data. The qualitative data were also presented thematically to support the quantitative data. The study revealed that the causes of truancy can be categorized into student related, family related and school related. Both teachers and students agreed that peer pressure is one of the causes of truancy. The study also showed that truancy brings about school drop-outs and affects students academic output. It was realized that most of the students who attended classes regularly performed better than their counterparts who absented themselves from classes on a regular basis. It was recommended among other things that all stakeholders should see to it that there are qualified counselors in all second cycle schools to assist students.
\end{abstract}

Keywords: Truancy, Peer group pressure, Bullying, Corporal punishment, School fees, School counselors.

\section{Contents}

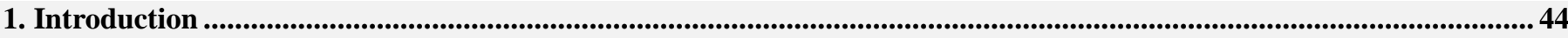

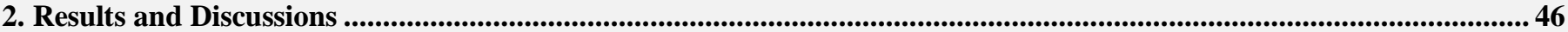

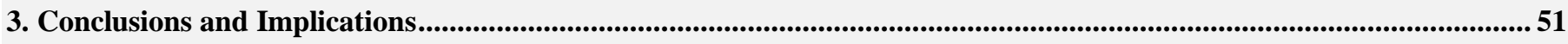

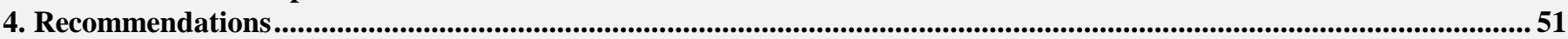

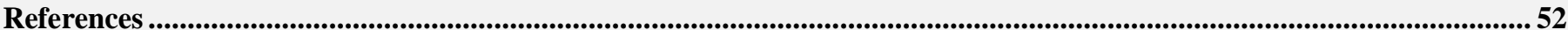

Citation | Gyimah Henry; Daniel Yelkpieri (2017). Truancy and its Influence on Students' Learning in Dormaa Senior High School. Asian Journal of Education and Training, 3(1): 43-52.

DOI:

$\operatorname{ISSN}(\mathbf{E})$ :

10.20448/journal.522.2017.31.43.52 Crossref

Licensed:

$2519-5387$

$\begin{array}{ll}\text { Licensed: } & \text { This work is licensed under a Creative Commons Attribution } 3.0 \text { License } \\ \text { Contribution/Acknowledgement: } & \text { All authors contributed to the conception and design of the study. }\end{array}$

Funding:

Competing Interests:

This study received no specific financial support.

Transparency:

The authors declare that they have no conflict of interests.

History:

The authors confirm that the manuscript is an honest, accurate, and transparent account of the study was reported; that no vital features of the study have been omitted; and that any discrepancies from the study as planned have been explained.

Ethical:

Publisher:

This 2 February 2017/ Revised: 20 February 2017/ Accepted: 8 March 2017/ Published: 24 March 2017

This study follows all ethical practices during writing.

Asian Online Journal Publishing Group 


\section{Introduction}

Ghana as a country expects all her children to attend school and attain the highest level of education to boost the human resource base. McWilliams and Kwamena-Poh (1975) note that, the main purpose of education whether formal or informal has been to produce a person who will be a useful member of the society. Harbinson and Mayers (1964) also claim that the higher the level of educational development of a country, the greater the range of economic development. All these point to the importance of education to the development of a nation hence the need to check truancy which is a set-back to education.

Truancy is described as the frequent unexcused absences from classes or compulsory schooling. A child is said to be truant if he is a wandering maniac and if he avoids school (Kochhar, 2000). According to the OJJDP (2001) truancy or unexcused absence from school has been linked to serious delinquent activity in youth and to significant negative behaviour and characteristics in adults. As a risk factor for delinquent behaviour in youth, truancy has been found to be related to substance abuse, gang activity, and involvement in criminal activities such as burglary, auto theft and vandalism. Everyday hundreds of thousands of youth are absent from school. Many large cities report staggering rates of truancy and chronic absenteeism. One of the variables that affect students' academic performance is attendance. There is a positive relationship between school attendance and school achievement, the more a student is present in class the more he or she is likely to perform in school activities (Pennola, 2004; Fareo, 2013). It implies that for academic excellence to be achieved there is the need for regular attendance at school.

Globally truancy has been found to be detrimental and it is prominent in developed countries such as the United States of America and the United Kingdom. These situations are worrisome because truancy is often one of the first and best indicators of academic failure, suspension, expulsion, delinquency, and later adult crime (Trujillo, 2006).

In Ghana, there is no available data nationwide on the state of truancy, some districts however have recorded high incidence of truancy and have taken steps to address it. At Atwima Mponua for instance, the assembly launched a campaign to end truancy within schools in 2010 by the District Chief Executive (DCE). This situation has resulted because of waterfalls discovered in the district which has attracted high patronage from students (Acheampong, 2010). In another development, Mr. J. H.Mensah the Headmaster of the Bisease Senior High School on addressing members of the School's Parent-Teacher-Association (PTA), said absenteeism and truancy would not be tolerated and should be seen as a thing of the past and that registered students who would stay away from classes would not be allowed to write their final year examination (Mensah, 2012). Absence from school affects pupils, students and teachers. High rate of truancy and school absenteeism for a class can disrupt teacher's ability to plan and present class work in a sequential and organized manner. This affects the progress of the entire students in the class. Many a time, it takes about two weeks for some students in Dormaa SHS to return from mid-term break. Worse of all, when school re-opens, it takes about a month for some students to report. Another worrying phenomenon is the rate at which students absent themselves after registration for the West African Senior Secondary Certificate Examination (WASSCE).

As a result of this behaviour three classes were asked to bring their parents to sign an undertaken on the $19^{\text {th }}$ of November, 2012 because majority of students in those classes refused to attend classes after the registration of the 2013 WASSCE. The classes were 4 Visual Arts, 3 Visual Arts and 4 Arts 3.

Complaints from some community elders, parents and teachers indicate that the rate of truancy in Dormaa Senior High School is high and worrying. It is very common to see students roaming about during contact hours. These students make their parents aware that they are going to school but will never get there.

\subsection{Purpose of the Study}

The purpose of the study is to investigate the influence of truancy on students' learning and to recommend measures that should be put in place to minimize truancy to the barest minimum.

\subsection{Research Questions}

Based on the stated research objectives, the study seeks to obtain answers to the following research questions:

1. What are the causes of truancy in Dormaa S.H.S?

2. How does truancy of students influence learning?

3. How does truancy affect youth skills development in the Dormaa-Ahenkro Municipality?

4. Which measures should be put in place to curb truancy in second cycle schools in Dormaa-Ahenkro Municipality?

\subsection{Significance of the Study}

It is hoped that through this research the causes of truancy and its influence on learning of students would be brought to the notice of Policy makers, educational authorities such as the Ghana Education Service (GES), Ministry of Education (MoE). The findings will also help parents and teachers to identify how they contribute to the truancy and absenteeism of their children. The information obtained in this work will add to the existing literature which will go a long way to help student researchers on similar work. Finally, guidance and counseling coordinators in schools will find the study very useful as it will serve as a source of material for effective counseling.

\subsection{Research Design}

The design used for the study was descriptive survey. This method describes and interprets what exists in its present form or condition, practice and process, trend and effect and attitude or belief. It deals with the normal or typical condition of a phenomenon under examination (Alhassan, 2012). The design is more appropriate because it enabled the researcher to explore the study area as much as possible to collect the needed data from relevant people. 


\subsection{Population, Sample, and Sampling Procedures}

The target population for the research included all the teachers and students in Dormaa Senior High School, the parents and opinion leaders in the Dormaa-Ahenkro Municipality. The students were selected from Form 2 and Form 3. This group of students has been in the school for at least 2 years and is better informed about the issue under study. The number of students in Form 2 was 588 whilst that of Form 3 was 568 bringing the total number of students in SHS 2 and SHS 3 to 1156. The breakdown of the sample has been presented in

Table 1.

Table-1. Sample of Teachers, Students, Parents and Opinion Leaders

\begin{tabular}{l|l}
\hline Name of Respondents & Number Selected \\
\hline Teachers & 20 \\
\hline Students (SHS 2) & 52 \\
\hline Students (SHS 3) & 48 \\
\hline Parents & 10 \\
\hline Opinion Leaders & 5 \\
\hline Total & $\mathbf{1 3 5}$ \\
\hline Source: Field work (2013)
\end{tabular}

The sampling method that was used in the selection of the sample for the study was simple random sampling and purposive sampling. The type of simple random sampling method that was used to select the students was the lottery method. The students were selected at random from the identified groups in order to give each member an equal chance of participating in the study. Out of the 1156 students in Form 2 and 3, 100 were selected using proportion to get the number that was representative of each year group, thus 52 in Form 2 and 48 in Form 3. Form 2 had 13 classes out of which at least 4 students were selected from each class. On the other hand, Form 3 had 12 classes out of which at least four students were selected from each class. The number of students selected in each case was based on proportion as indicated earlier.

In selecting participants, the researchers wrote 'Yes' and 'No' on pieces of paper and they were used in place of the names of the students in each class. The 'Yes'and 'No'were put in a bowl and thoroughly mixed. One was picked at a time by a student after which the content was thoroughly mixed again before the next one was picked. This continued until the last piece of paper was picked and that was done for all the classes in Form 2 and 3 until the required 100 respondents were obtained. Those who picked 'Yes' were selected as respondents whilst those who picked 'No' were left out.

Purposive sampling method was used to select 20 teachers, 10 parents and 5 opinion leaders. These groups were deliberately selected because the researchers feel that they were well informed about the subject matter under study. The teachers were selected from the school whilst the parents and opinion leaders were selected from the locality because they have a fair idea about the establishment of the school and the behaviour of students in the school.

\subsection{Research Instrument}

The instrument used for the study was semi-structured questionnaire and semi-structured interview schedule. The questionnaire was given to teachers and students because it is easier to administer questionnaire than an interview. The items in the questionnaire included a personal data from the respondent with close-ended and open-ended sections. The research question 1 was on the causes of truancy in Dormaa Senior High School, question 2 was on the influence of truancy on learning, question 3 was on the effects of truancy on youth skills development in the Dormaa-Ahenkro Municipality and question 4 was on measures for curbing truancy in second cycle schools in Dormaa Municipality.

The teachers and students were given close-ended items and were asked to use a 5-point Likert Scale from 1 to 5 where 1 stood for strongly disagree and 5 stood for strongly agree to rate the statements in answering each question. The open-ended questions provided an opportunity to respondents to express their views on other issues that were not included in the close-ended questions.

In the case of the parents and opinion leaders, semi-structured interview questions were used to obtain their views by recording the answers they gave. The semi-structured schedule was chosen because it enabled the respondents to probe further whenever the need arose. In the presentation of the verbatim quotations respondents were given identifiers such as PR which represents parent respondent and OL for opinion leaders. This enables the reader to know the level of participation of respondents.

\subsection{Content Validity}

The questionnaire and the interview guide were designed by the researcher and given to colleagues to assess the face validity of the content. After the corrections were made, they were pilot tested using 10 students, 5 teachers, 2 parents and 1 opinion leader. The results helped the researchers to improve the items. The questionnaires were pretested in Christ Apostolic Church SHS was chosen because it is in the same geographical location as the study area and therefore had similar characteristics.

The reliability of the questionnaire was established by the use of the test-retest reliability. Tuckman (1994) is of the view that 'one way to measure reliability is to give the same people the same test on more than one occasion and then compare each person's performance on the different testings'. The results of the tests were subjected to Cronbach's coefficient alpha to determine the internal consistency of the items which yielded high reliability coefficients of .78 in each case. Tuckman (1994) argues that 'reasonably high coefficients are' indications of high quality.

In the case of the interview schedule the researchers interviewed parents and opinion leaders and their responses obtained were similar which implied that the questions were good for the data collection. The questionnaire was then administered to the teachers and students whilst the parents and opinion leaders were interviewed by the researchers. 


\section{Results and Discussions}

The questionnaire were collected, verified, collated and analyzed with the use of Statistical Products and Service Solutions (SPSS). Means and standard deviations were the descriptive statistics used in the analysis of the questionnaire of teachers and students. The recorded interview of the parents and opinion leaders were transcribed and analyzed manually based on the themes of the study. In the first section, the researchers present the background information of respondents and proceed to present the results of the study based on the research questions and relate the findings to the literature. The various data are presented by using descriptive statistics such as percentages, means and standard deviations. The presentation of the findings was done in the order in which the research questions were presented. The questionnaire data of teachers were presented first, followed by that of the students and finally the interviews of parents and opinion leaders were triangulated with the questionnaire data.

The 100 student respondents were selected from Form 2 and form 3. The researcher considered the number of years of students in school and their experience. Form 2 and 3 are better experienced and informed about the subject matter of the study than Form 1 students. Because the number of students in Form 2 outnumbers Form 3, proportionally their percentages are $52.9 \%$ and $47.1 \%$ respectively.

Parental occupation has the potential to influence students' school attendance and completion. Table 2 represents the distribution of students according to the occupation of their parents.

Table-2. Distribution of Students According to Parental Occupation

\begin{tabular}{l|l}
\hline \multicolumn{2}{c}{ Table-2. Distribution of Students According to Parental Occupation } \\
\hline Parental occupation & Percentage (\%) \\
\hline Public servant & 25.7 \\
\hline Civil servant & 15.7 \\
\hline Farming & 42.9 \\
\hline Self employed & 15.7 \\
Source: Field work (2013)
\end{tabular}

In Table 2 the percentage of parents engaged in farming is $42.9 \%$, public servants $25.7 \%$, and self employed $15.7 \%$. This suggests that majority of the parents of the students are farmers. Since most parents are engaged in subsistence farming, their income levels are low hence they are unable to pay the fees of their wards in time. This might be the reason why majority of students report late when school re-opens and also, some sacked for nonpayment of school fees.

The researchers observed that the type of family a student belongs to can contribute to whether the student will be truant or not. Students from single parent families are likely to be truant than those who stay with both parents. The data collected show that $82.9 \%$ of the students stay with both parents while $17.1 \%$ live with either the father or mother alone. From this, it could be deduced that, many students have their fathers and mothers still married.

\section{Research Question One: What are the Causes of Truancy in Dormaa Senior High School?}

The problem of truancy affects the students, school and the community. This question sought to examine the contributory factors leading to truancy in Dormaa SHS. Views solicited from teachers and students are presented in Table 3.

Table-3. Views of Teachers and Students on the Causes of Truancy in Dormaa Senior High School

\begin{tabular}{|c|c|c|c|c|c|c|}
\hline & \multicolumn{3}{|c|}{ Teachers } & \multicolumn{3}{|c|}{ Students } \\
\hline & WM & Std & I & WM & Std & I \\
\hline A student's low intelligent quotient is a contributory factor of becoming a truant. & 3.45 & 1.19 & $\mathrm{~N}$ & 3.91 & 1.33 & $\mathrm{~N}$ \\
\hline Parents' inability to pay school fees. may result in the student being truant. & 4.00 & 1.1 & A & 4.01 & 1.28 & A \\
\hline A poor teaching method is a contributory factor to student's truancy. & 2.50 & 1.10 & $\mathrm{D}$ & 3.13 & 1.40 & $\mathrm{~N}$ \\
\hline Lack of learning materials by the student may lead to truancy. & 3.05 & 1.05 & $\mathrm{~N}$ & 3.83 & 1.29 & $\mathrm{~N}$ \\
\hline Peer group pressure is a cause of student's truancy. & 4.55 & 0.76 & A & 4.30 & 1.17 & A \\
\hline Single Parenthood is a cause of truancy. & 3.20 & 1.10 & $\mathrm{~N}$ & 3.36 & 1.44 & $\mathrm{~N}$ \\
\hline Bullying and corporal punishment are contributory factors to truancy. & 3.45 & 1.05 & $\mathrm{~N}$ & 3.89 & 1.29 & $\mathrm{~N}$ \\
\hline An authoritarian method in the school is a contributory factor to truancy. & 2.30 & 1.21 & $\mathrm{D}$ & 3.37 & 1.36 & $\mathrm{~N}$ \\
\hline Mean of means & 3.05 & 1.07 & $\mathrm{~N}$ & 3.39 & 1.19 & $\mathrm{~N}$ \\
\hline
\end{tabular}

Source: Field work (2013)

The data presented in Table 3 revealed a weighted mean of 4.55 and a standard deviation of 0.76 which means that, teachers agreed with the view that, peer group pressure is a cause of student's truancy. A close examination from the perspectives of students show that they agreed with teachers that, peer group pressure is a cause of student's truancy. A parent indicated that, "the students themselves contribute to truancy when they form bad company". (PR6) (Adewole, 1988) observes that truancy is caused by student over-population, shortage of teachers, incessant strike and work-rule, undue application of corporal punishment asd well as peer influence at school. The researchers are of the view that, students in SHS are adolescents who at this stage, take friends in the school and spend more time with them than their parents and so if a student gets involve in a bad friendship, s/he is likely to copy the behaviour of the friend. This is in agreement with the view that, truant peer-groups tend to influence other students to absent themselves from school to play truancy (Sekyere, 2012).

The weighted mean of 2.30 and a standard deviation of 1.21 meant that teachers disagreed with the view that, an authoritarian leadership style in the school is a contributory factor to truancy. The students on the other hand had neutral view which is contrary to that of the teachers. The respondents' views are in disagreement with the view expressed by Farrant that authoritarian methods in the school bring about truancy (Farrant, 2004). Trujillo holds contrary view and has the assertion that, students have the best attendance in authoritative schools; -those that make high demands and provide high level of support (Trujillo, 2006). This is in line with the view of the teachers and it is 
supported by the researchers because, authoritarian methods in school bring about high level of discipline on the part of students and improve attendance as well as academic work.

The data presented in Table 3 revealed a weighted mean of 4.01 and a standard deviation of 1.28 which means that, students agreed with the view that, parents' inability to pay school fees may result in the student being truant. The teachers shared in this view. Among the 10 parents interviewed, they all shared similar views. On the causes of truancy in Dormaa Senior High School, a parent was of the view that, "failure on the part of parents to provide the basic needs of the students' leads to students' truancy". (PR1) Most especially the refusal to pay the school fees results in the sacking of students and since most of them are teenagers and feel shy, they refuse to attend school in the subsequent days until the school fees is settled. According to Sekyere, students whose parents are too poor to provide them with their basic necessities such as food, clothing and school materials tend to absent themselves from school to engage in economic activities to fend for themselves (Sekyere, 2012).

In the researcher's zeal to gather more information, they gave teacher and student respondents the opportunity to provide more information through the open-ended questionnaire. A teacher indicated that one of the reasons for truancy is "failure to provide the necessary support to students". Another teacher said that "lack of disciplinary measures contributes to truancy" and that "truancy is also caused by broken homes and lack of parental care or control". This finding is agreement with Ma'aruf (2005) who argues that poor relationship between parents and children, and lack of parental interest in child's welfare are contributory factors to students' truancy. Another parent notes that "most parents do not visit the students in school to find out their wellbeing as well as attendance and academic performance". (PR4) The researchers agree with the respondents to a large extent because if students are not given the needed support from home they cannot go to school and if they even go to school there is very little they can do because they may not have writing materials such as pens, pencils, exercise book among others. An opinion leader observed that "most of the parents do not know the importance of education and so spend money on other things instead of spending the money on their children's schooling". Among these are "the purchase of different types of cloth for funeral activities to the detriment of students' school fees of their wards".(OL1) In the same vein, children from broken homes do not get the required support from both parents and therefore are not motivated to go to school. Apart from these, students from such homes lack discipline and control. However, when these factors are checked, truancy will be reduced to the barest minimum. Parents need to show interest in students' education and provide the necessary support to ensure that they attend school regularly. When this is done students would have no excuse to stay home when school is in session. Failure on the part of students to attend school would be met with displeasure from parents and the school.

The students said that teachers force them to buy their books and also patronize their extra-classes and that contributes to truancy. In a situation where students are forced by teachers to buy their books and attend extra classes give rise to tension and unnecessary anxieties for students who come from low income homes who cannot afford to pay. Other causes outlined are "teachers who do not attend class regularly bring about truancy" and "overloaded curriculum is a contributory factor to truancy". In line with this an opinion leader pointed out that "some teachers have lackadaisical attitude and so neglect their duties of ensuring regular attendance of students". (OL 5) These are factual and hence school authorities should take steps to address them. To a large extent these factors contribute to students' truancy because when a teacher forces students to buy his or her books and the students do not have money they will not come to school. On the other hand, if the teacher himself is not regular to school it gives the students the leeway to stay home with the excuse that the teacher will not come to school.

Generally, a mean of means of 3.05 and a standard deviation of 1.07 signify that the teachers have neutral stance with the views expressed in Table 2 on causes of truancy. The students had similar view to that of the teachers as they also had neutral stance generally, on the views expressed on the causes of truancy. The researchers are of the opinion that, all the views expressed in the questionnaires are contributory factors to truancy except, "the authoritarian method in the school". This is because in authoritarian school, there is strict enforcement of rules and regulations. According to Kochhar, the mentally dull child finding school work beyond his power of assimilation, cuts classes and runs away from school (Kochhar, 2000). The researchers agree with Kochhar because a student who does not perform well in class will not have the motivation to attend classes regularly and this can bring about truancy.

\section{Research Question Two: How does Truancy of Students affect their Learning?}

Students who play truancy have the lowest academic achievement rate, and are likely to drop out of school. This question sought to examine the effects of truancy on learning of students. Views solicited from teachers and students are presented in Table 4 .

Table-4. Views of Teachers and Students' on the Influence of Truancy on Students' learning

\begin{tabular}{|c|c|c|c|c|c|c|}
\hline & \multicolumn{3}{|c|}{ Teachers } & \multicolumn{3}{|c|}{ Students } \\
\hline & WM & Std & I & WM & Std & $\mathbf{I}$ \\
\hline Truancy results in poor academic performance of students & 4.75 & 0.44 & $\mathrm{~A}$ & 4.66 & .85 & $\mathrm{~A}$ \\
\hline Truancy is a major cause of examination malpractices among students & 4.15 & 0.93 & A & 4.59 & .81 & A \\
\hline Students who miss classes always havearrears of learning tasks. & 4.00 & 1.02 & A & 4.14 & 1.15 & A \\
\hline Truancy brings about delay of teachers inthe completion of their syllabi & 3.30 & 1.26 & A & 3.40 & 1.54 & $\mathrm{~N}$ \\
\hline $\begin{array}{l}\text { Truant students do not get full complement of assignments for continuous } \\
\text { assessment. }\end{array}$ & 4.35 & 0.75 & A & 4.33 & 1.18 & A \\
\hline Mean of means & 4.11 & 0.88 & A & 4.22 & 1.11 & \\
\hline
\end{tabular}

The data presented in Table 4 revealed a weighted mean of 4.75 and a standard deviation of 0.44 which means, teachers agreed with the view that truancy results in poor academic performance of students. The students shared in the same view with teachers. This is in line with the view that truant students achieve less academically because 
students do not spend much time on their books learning when they are absent from class (Ma'aruf, 2005; Eastman et al., 2007). Learning is a continuous process; hence frequent absences from class results in poor academic performance unless s/he is a gifted student.

The data presented in Table 4 revealed a weighted mean of 4.14 and a standard deviation of 1.15 which means students agreed with the view that students who miss classes always have arrears of learning tasks. The teachers shared in the same view with student. A student who absents him or herself from class will have to copy notes and may not understand what was taught in his or her absence. School attendance has a positive effect on education (Nwadiani, 1994; Oghuvu, 2006; Sekyere, 2012).

The data in Table 4 further revealed a weighted mean of 4.59 and a standard deviation of 0.81 which means students agreed to the view that, truancy is a major cause of examination malpractices among students. The teachers held the same view. An opinion observed that "truancy brings about examination malpractices because truant students who will be ill-prepared towards examination and wish to pass at all cost employ all manner of tactics during the WASSCE". (OL3) This is obvious since examination requires adequate preparation of a student before he or she sits for it. In instances where students are not well prepared, they tend to indulge in malpractices during the examination.

Generally, a mean of means of 4.22 and a standard deviation of 1.11 signify that, the students agreed with the views expressed on the influence of truancy on learning. In the researchers' opinion all the views expressed by the students and teachers on the influence of truancy on students' learning, hence the need for stakeholders to address them.

In the quest to get additional views from teachers, they were asked to give their opinion on the effects of truancy on students' learning in an open-ended questionnaire. It could be realized the teachers indicated that, "truancy on the part of students discourages teachers from teaching", and others said that "the possibility of becoming drop-out is high" while some teachers said "truancy leads to rote learning" This present finding agrees with Peck (2002) who said among other things that truancy have undermined effective teaching-learning processes which has made some teachers helpless. All these effects can affect student's learning hence parents and teachers should collaborate to curb them.

\section{Research Question Three: How does Truancy Affect Youth Skills Development in the Dormaa-Ahenkro Municipality?}

This question sought to examine the effects of truancy on youth skills development in the Dormaa-Ahenkro Municipality. One important reason for educating the youth is to develop their skills of literacy, numeracy and communication which will help them in the near future to become responsible citizens and not a burden on the society. Views solicited from teachers are presented in Table 5.

Table-5. Views of Teachers and Students' on the Effects of Truancy on Youth Skills Development in the Dormaa-Ahenkro Municipality

\begin{tabular}{|c|c|c|c|c|c|c|}
\hline & \multicolumn{3}{|c|}{ Teachers } & \multicolumn{3}{|c|}{ Students } \\
\hline & WM & Std & I & WM & Std & I \\
\hline $\begin{array}{l}\text { Truant students will not be able to develop fully the skills of literacy, } \\
\text { numeracy and communication }\end{array}$ & 3.85 & 1.27 & $\mathrm{~N}$ & 3.97 & 1.14 & $\bar{N}$ \\
\hline $\begin{array}{l}\text { Truancy affects the development of Vocational and Technical skills of students in } \\
\text { Dormaa Municipality. }\end{array}$ & 3.85 & 0.81 & $\mathrm{~N}$ & 3.94 & 1.17 & $\mathrm{~N}$ \\
\hline Truant students have less chance of going for further studies. & 4.10 & 0.97 & A & 4.04 & 1.25 & A \\
\hline $\begin{array}{l}\text { Truant students are far more likely not to graduate from SHS hence theybecome a } \\
\text { burden in the Municipality. }\end{array}$ & 4.00 & 1.07 & A & 4.13 & 1.13 & A \\
\hline $\begin{array}{l}\text { Truant students may end up in teenage pregnancy, prostitution, contraction of } \\
\text { Sexually Transmitted Diseases (STDs) and arm robbery which hinders the } \\
\text { progress of the Municipality. }\end{array}$ & 4.30 & 0.80 & A & 4.33 & 1.07 & A \\
\hline Mean of means & 4.02 & 0.98 & & 4.08 & 1.15 & \\
\hline
\end{tabular}

The data presented in Table 5 revealed a weighted mean of 4.30 and a standard deviation of 0.80 which means that teachers agreed with the view that truant students may end up in teenage pregnancy, prostitution, contraction of Sexually Transmitted Diseases (STDs) and arm robbery which is not good for national development. The students held similar view to that of the teachers. A woman who shared her son's experience observed that "peer group influence brings about drunkenness, drug and substance abuse and students who are addicted to such acts refuse to attend classes and go to hide-out places". (PR 8) The views expressed are obvious because a truant student who loiters around is prone to vices such as drug abuse, arm robbery and the like. Share a similar view that truant adolescents have been reported to engage in risky sexual practice, illicit drug use, alcohol and cigarette smoking. This is in agreement with the view that truant youth are likely to experience higher rates of unintended pregnancies, more criminal behaviour, greater instability in career paths, higher rates of unemployment, and lower lifetime earnings (Eastman et al., 2007). This is in agreement with the view that, truancy has been clearly identified as one of the early warning signs that youth are headed for potential delinquent activity, social isolation, or educational failure (DeKalb, 2000).

On the other hand, the weighted mean of 3.85 and a standard deviation of 0.81 in Table 5 meant that, teachers assumed a neutral stance on the view expressed which states that truancy affects the development of vocational and technical skills of students in Dormaa Municipality. The students also held similar opinion to that of the teachers. The researcher disagrees with them because a truant student will not be able to develop fully Vocational and Technical skills.

Table 5 revealed a weighted mean of 4.04 and a standard deviation of 1.25 which means that students agreed with the view that truant students have less chance of going for further studies. The teachers also shared in this view. 
A truant student has the least probability to excel in WASSCE which serves as the major certificate for entry into any tertiary institution. According to the Methodist Bishop of Sunyani Diocese Right Reverend Kofi Asare Bediako in addressing SHS students in Sunyani on February 7, 2013, expressed his unhappiness particularly, with the final year students in SHS who register for the WASSCE and indulge in truancy (GNA, 2013). The above findings are shared by Fareo (2013) when she said "truancy hinders students' learning which could lead to poor academic performance".

Generally, a mean of means of 4.02 and 4.08 and standard deviations of 0.98 and 1.15 respectfully for teachers and students signify that they agreed with the views expressed pertaining to the effects of truancy on youth skills development in the Dormaa-Ahenkro Municipality. A parent stressed that, "an uneducated youth will lead to the retardation of the development of the Municipality". (PR6) This position is in line with Fareo (2013) who argues that constant absence from school has serious negative consequences on both truant youth themselves and the communities, which suffer both short term and long-term threats to public safety. However, if truancy is checked, it will go a long way to help in youth skills development.

In order to get additional information on the effects of truancy on youth skills development in the DormaaAhenkro Municipality, teachers were given open-ended questionnaire to give their opinion. The responses from the open-ended questions found that teachers indicated that "truancy delay the productive growth of the youth" and that "truant students can become social misfit". While others also were of the view that "truancy leads to smoking and drunkenness in the youth which may bring about health problems". The effects of truancy on youth skills development are devastating and so every well meaning society should do well to address them. An opinion leader suggested that, "the Municipality should establish scholarship schemes to support the students with financial difficulties.(OL5)

\section{Research Question Four: Which Measures should be Put in Place to Curb Truancy in Second Cycle Schools in Dormaa Municipality?}

Research question four explored teacher and student respondents' views on the measures that should be put in place to curb truancy in second cycle schools in Dormaa Municipality. The views of teacher and student respondents are presented in Tables 6.

Table-6. Views of Teachers and Students on the Measures to Curb Truancy in Second Cycle Schools in Dormaa Municipality

\begin{tabular}{|c|c|c|c|c|c|c|}
\hline & \multicolumn{3}{|c|}{ Teachers } & \multicolumn{3}{|c|}{ Students } \\
\hline & WM & Std & I & WM & Std & I \\
\hline $\begin{array}{l}\text { Improving parent-teacher communication on student's progress in school } \\
\text { will reduce truancy in second cycle schools in the Municipality. }\end{array}$ & 4.75 & 0.44 & $\bar{A}$ & 4.29 & .92 & $\overline{\mathrm{A}}$ \\
\hline $\begin{array}{l}\text { Bye-laws should be made by the Municipal Assembly to compel students } \\
\text { to attend school regularly. }\end{array}$ & 3.50 & 1.24 & A & 4.30 & .97 & A \\
\hline $\begin{array}{l}\text { Parents and guardians should provide students with their basic needs to } \\
\text { enable them attend school regularly. }\end{array}$ & 4.65 & 0.49 & A & 4.63 & .64 & A \\
\hline $\begin{array}{l}\text { Form masters should visit classrooms regularly and ensure that attendance } \\
\text { register is marked and to find out students who have been absenting } \\
\text { themselves. }\end{array}$ & 4.70 & 0.47 & A & 4.57 & .91 & A \\
\hline $\begin{array}{l}\text { House masters should do routine checks to find out boarders who do not } \\
\text { stay on campus and those who sleep in dormitories during classes. }\end{array}$ & 4.55 & 0.95 & $\mathrm{~A}$ & 4.63 & .77 & $\bar{A}$ \\
\hline $\begin{array}{l}\text { Improving counseling services in second cycle schools will reduce the } \\
\text { incidence of truancy. }\end{array}$ & 4.55 & 0.69 & $\mathrm{~A}$ & 4.36 & .92 & A \\
\hline Mean of means & 4.45 & 0.71 & & 4.46 & .85 & \\
\hline
\end{tabular}

The data presented in Table 6 revealed a weighted mean of 4.75 and a standard deviation of 0.44 which means that teachers agreed with the view that improving parent-teacher communication on student's progress in school will reduce truancy in second cycle schools in the Municipality. The students shared in the view of the teachers. When parents communicate with teachers about the well being of their wards and also visit them occasionally, it will go a long way to reduce the incidence of truancy.

The data in Table 6 further revealed a weighted mean of 4.70 and a standard deviation of 0.47 which means that teachers agreed with the view that form masters should visit classrooms regularly and ensure that attendance registers are marked and to find out students who have been absenting themselves without any tangible reason. An opinion leader observed that"the school authorities have relaxed in their disciplinary actions and this has paved way for most students to be truant". In terms of disciplinary measures, "the mission schools are second to none and hardly will you find students in such schools playing truancy and such act should be emulated by public schools". (OL5) From the researcher's point of view, if form masters are able to do routine checks on students, it will bring truancy to the barest minimum.

Finally the weighted mean of 3.50 and a standard deviation of 1.24 meant that teachers had neutral stance on the view that bye-laws should be made by the Municipal Assembly to compel students to attend school regularly. Students agreed to this view, which is contrary to the view of the teachers. Teachers and parents can team up to prevent students from playing truancy without necessarily putting in place bye-laws by the Municipal Assembly.

The data in Table 6 also revealed a weighted mean of 4.63 and a standard deviation of 0.64 which means that students agreed with the view that parents and guardians should provide students with their basic needs to enable them attend class regularly. The teachers held similar views as that of the students. A sub-chief of the Dormaa Traditional area said that, "there is a scholarship scheme known as Dormaa Municipal Education Fund (DOMEF) which has been established to support needy students in the Municipality".(OL1) Students should be provided with their basic needs to enable them attend classes regularly (Sekyere, 2012; Yelkpieri, 2016). 
Generally, a mean of means of 4.46 and a standard deviation of 0.85 signify that, the students agreed with the views expressed on the measures that should be put in place to curb truancy in second cycle schools in Dormaa Municipality. One of the opinion leaders said, "parents should be sensitized on the need to educate their children", "school authorities should liaise with parents to monitor the movement of their children in and out of school".(OL2) It should be noted that the teachers shared in all the views of the students except, the view which talks about institution of bye-laws to compel students to attend classes.

In order to obtain further solutions to the issue of truancy, the teachers were asked to answer an open-ended questionnaire. Teachers said that "students should be motivated and encouraged by teachers on the importance of education". Aside that others were of opinion that "teachers should vary their methods of teaching by encouraging students participation in their teaching and learning which will help reduce truancy".

It could be noticed from the students' views expressed through the open-ended questionnaire that, "parents should pay regular visit to their children when they are in school", others said that, "truant students must be dealt with seriously in the school and also be reported to their parents". Another view was that "there should be public education on the importance of schooling to the individual and the society". The battle against truancy should be fought from the family, the school and the society.

Concerning the influence on truancy they were of the view that, "it leads to poor academic performance since the students will not attend school regularly". This finding finds support in Oghuvu (2006) and Nwadiani (1994) that truancy could lead to poor academic outcomes. To buttress the effects of truancy on academic performance of students in Dormaa SHS, some students were selected from some classes at random using their registers and report cards. These were form 2 and 3 presented in Table 7. In form 2, five classes offering the four programmes namely General Arts, Visual Arts, Science and Business were selected. The table indicates the number of days in attendance and position in class for the first term. The names of the students have been replaced with numbers starting from 1 to 15.

Table-7. Five classes showing attendance and position of some students in form two

\begin{tabular}{|c|c|c|c|c|}
\hline Student number & Class & $\begin{array}{l}\text { Attendance } \\
\text { out of } 63 \text { days }\end{array}$ & Position in class & Number on roll \\
\hline 1 & 2 Arts 1 & 57 & 11 & 77 \\
\hline 2 & 2 Arts 1 & 53 & 38 & 77 \\
\hline 3 & 2 Arts 1 & 22 & 76 & 77 \\
\hline 4 & 2 Visual Art & 56 & 3 & 30 \\
\hline 5 & 2 Visual Art & 43 & 15 & 30 \\
\hline 6 & 2 Visual Art & 37 & 25 & 30 \\
\hline 7 & 2 Science 1 & 61 & 12 & 71 \\
\hline 8 & 2 Science 1 & 52 & 32 & 71 \\
\hline 9 & 2 Science 1 & 51 & 56 & 71 \\
\hline 10 & 2 Home Economics & 58 & 04 & 62 \\
\hline 11 & 2 Home Economics & 54 & 28 & 62 \\
\hline 12 & 2 Home Economics & 48 & 57 & 62 \\
\hline 13 & 2 Business 1 & 63 & 03 & 30 \\
\hline 14 & 2 Business 1 & 57 & 19 & 30 \\
\hline 15 & 2 Business 1 & 26 & 29 & 30 \\
\hline
\end{tabular}

From table 21, it could be realized that most of the students who attended class regularly performed better as compared to those who were absent for ten or more days. In each class, the first on the list of the three students selected, attended classes in more days than the preceding ones. The classes were 2 Arts 1, 2 Visual Arts, 2 Science 1, 2 Home Economics, and 2 Business 1.

For instance comparing the three students in 2 Arts 1 , student number 1 attended class for 57 out of 63 days and was $11^{\text {th }}$ in that class out of 77 students. Student number 2 attended class for 53 out of 63 days and came $38^{\text {th }}$ out of 77 students. Student number 3 attended class for 22 out of 63 days and was $76^{\text {th }}$ out of 77 students. This applies to the other classes. From this it could be deduced that, truancy has a significant effect on academic performance. This finding is supported by Fareo (2013) who found "significant relationship between truancy and academic performance of students". Nonetheless other factors such as intelligence, dullness, and the method of teaching can influence academic performance.

The same was done for the form three classes as presented in table 22 indicating five classes from the four programmes offered in the school namely General Arts, Science, Visual Arts and Business.

In table 22, it could be realized that among the three students in each class, the first person attended class more than the second student. The same applies to their respective positions in class. The first person on the list in each class performed better than the second, and the second than the third. There may however be an exceptional student who may absent himself for a number of days yet perform better in class or a student who may attend classes throughout the term yet perform below average. It should however be noted that these were few classes chosen out of the lot. Comparing the three students in 3 Science 1, student number 4 attended class for 60 out of 63 days and was $1^{\text {st }}$ out of 70 students, student number 5 attended class for 55 out of 63 days and was $22^{\text {nd }}$ out of 70 students, student number 6 attended class for 38 out of 63 days and was $66^{\text {th }}$ out of 70 students. The data highlight the serious effects of truancy on students' academic performance in school. It could be deduced that truancy has significant influence on students' academic performance. 
Table-8. Five classes showing attendance and position of some students in form three

\begin{tabular}{l|l|l|l|c}
\hline Student number & Class & Attendance out of 63 days & Position & Number on roll \\
\hline 1 & 3 Arts 2 & 60 & 01 & 81 \\
\hline 2 & 3 Arts 2 & 55 & 37 & 81 \\
\hline 3 & 3 Arts 2 & 40 & 77 & 81 \\
\hline 4 & 3 Science 1 & 60 & 01 & 70 \\
\hline 5 & 3 Science 1 & 55 & 22 & 70 \\
\hline 6 & 3 Science 1 & 38 & 66 & 70 \\
\hline 7 & 3 Visual Art & 58 & 04 & 25 \\
\hline 8 & 3 Visual Art & 50 & 12 & 25 \\
\hline 9 & 3 Visual Art & 45 & 20 & 25 \\
\hline 10 & 3 Business 1 & 57 & 02 & 46 \\
\hline 11 & 3 Business 1 & 50 & 26 & 46 \\
\hline 12 & 3 Business 1 & 28 & 37 & 46 \\
\hline 13 & 3 Home Economics & 47 & 19 & 55 \\
\hline 14 & 3 Home Economics & 43 & 42 & 55 \\
\hline 15 & 3 Home Economics & 34 & 51 & 55 \\
\hline Sour & 3 & & & \\
\hline
\end{tabular}

Source: Class attendance register and Students' report cards (2013)

When an opinion leader was asked about the influence of truancy on youth skills development, he said "such students will not be able to develop fully the skills of literacy, numeracy and communication". (OL4) Also "the probability of such students going for further studies is less; hence they become a burden to family and society at large". (OL2) This finding agrees with Fareo (2013) when she indicated that "constant absence from school has serious negative consequences both for truant youth themselves and for communities, which suffer both short-term and long-term threats to public safety". When a question was on remedy to the issue of truancy was brought up a parent said, "parents should provide the basic needs of students and pay regular visits to their wards and also entrust them to the care of teachers to monitor them in school". (PR3)

\section{Conclusions and Implications}

Based on the findings the researchers have drawn the following conclusions:

The causes of truancy are principally peer group pressure, failure of parents to provide the basic needs of their wards and poor monitoring on the part of teachers and parents. This means that truancy is a multi-dimensional issue that must be tackled from all fronts to ensure that it is curbed or minimized in schools. Unless serious steps are taken, it has the potential to derail the youths' future.

The influence of truancy on students' learning is that, it leads to poor performance of students in academic work as well as internal and external examination. It was also found that, truancy leads to examination malpractices when students do not prepare adequately before they go in for examination. Therefore, truancy poses a serious threat to educational development and no effort should be spared to curb it.

The effect of truancy on the society is that, truant students who are not able to complete their course become a burden to their families and the society because they might not be able to develop fully the skills of literacy, numeracy and communication and so most of them will be unemployed. Education should therefore be made affordable for many students to remain in school. Government and other stakeholders of education should assist schools with their basic needs such as text books, computers and other ICT facilities, and support needy students by providing them with scholarships.

It was realized that, truancy could be brought to the barest minimum if parents provide the needs of their wards and advice them on the need to concentrate on their schooling in order to have meaningful life in future.

\section{Recommendations}

From the results of the study, the following recommendations are made:

1. The study found that there was no collaboration between and the school and parents in terms of monitoring students' movements. The study recommends that, parents and guardians should collaborate with school authorities and teachers to monitor students in and out of school compound to reduce the incidence of truancy.

2. The study found out that many students are driven home for non-payment of school fees. The study recommends that, parents who have difficulty in the payment of fees should arrange with the school authorities to pay by installments in order to avoid the student being sent home.

3. Non-provision of students' basic needs such as textbooks, writing materials among others is the main cause of truancy. It is incumbent on parents to provide all other needs of their wards most especially the girls who are vulnerable, to enable them stay in school and learn.

4. It was found that teachers force students to buy books and pay for extra classes. The study recommends that teachers should not force students to buy books or patronize any extra classes since this creates an unnecessary tension for students.

5. Non-enforcement of disciplinary measures encourage students to engage in truant behaviours. The school authorities should put in place negative sanctions or punishments such as internal suspension with hard labour to truant students to serve as a deterrent to others.

6. Guidance and counseling coordinators in second cycle schools should do well to meet truant students from time to time and counsel them on the need to be punctual in class and to participate in teaching and learning.

7. Ignorance on the part of some parents of the importance of education is said to be another factor The Municipal Assembly should liaise with the Ghana Education Service in the Municipality to sensitize all stakeholders of education on the need to prioritize education of the children in the Municipality. 
8. The study found that some teachers' absence paved way for truant students to be absent. The study recommends that heads of schools should ensure that teachers are punctual in class.

\section{References}

Acheampong, K.D., 2010. Keeping truant children in school-Adansi North initiative. Retrieved from www.graphic.com.gh [Accessed July 25, 2012].

Adewole, E.E., 1988. Truancy in secondary schools; causes, remedies and implications for administration. Ife Journal of Theory and Practice in Education, 2: 4-17.

Alhassan, S., 2012. Research methods in educational administration and management. Winneba: University of Education.

DeKalb, J., 2000. Student truancy. Retrieved from www.kidsource.com/education/student.truancy.htm/ [Accessed July 07, 2013].

Eastman, G., S.M. Cooney, C. O'Connor and S.A. Small, 2007. Finding effective solutions to truancy. Retrieved from Whatworks.uwex.edu/attachment/whatworks_05.pdf [Accessed July 10, 2013 ].

Fareo, D.O., 2013. Truancy and academic performance of secondary school students in South Western Nigeria: Implication for counseling. International Journal for Cross-Disciplinary Subjects in Education, 3(2): 1424-1428. View at Google Scholar $\mid$ View at Publisher

Farrant, J.S., 2004. Principles and practice of education. 19th Edn., England: Pearson Education Limited.

GNA, 2013. Truancy and absenteeism are the main causes of examination malpractices. Retrieved from http://graphic.com.gh/Education/Truancy-and-absenteeism-are-themain-causes-of-examination [Accessed February 11, 2013].

Harbinson, F. and C.A. Mayers, 1964. Education manpower and economic growth: Strategies of human resource development. New York: McGraw-Hill.

Kochhar, S.K., 2000. Secondary school administration. New Delhi: Sterling Publishers Private Limited.

Ma'aruf, I., 2005. Truancy among secondary school students in Kano City: Causes and remedies. Unpublished P.G.D.E Project, Federal College of Education, Kano.

McWilliams, H.O.A. and M.A. Kwamena-Poh, 1975. The development of education in Ghana: An outline. London: Longman Group Ltd.

Mensah, J.H., 2012. Bisease SHS would not tolerate absenteeism. Available from vibeghana.com/.../bisease-shs-would-not-tolerateabsenteeism-mensah/ [Accessed June 06, 2013].

Nwadiani, M., 1994. Managing pupils attendance data for computerization. A Paper Presented at the NIERA-Computerization of Educational Data Conference, University of Benin, 21-24 June.

Oghuvu, E.P., 2006. Data inquiry and analysis for effective administration. A comparative study of private and public secondary schools. Journal of Social Science, 13(3): 205-213. View at Google Scholar

OJJDP, 2001. Truancy reduction: Keeping students in school. Retrieved from http://paschoolperformance.org/doc/7 [Accessed July 07, 2013]

Peck, C.K., 2002. Personality of high school truants. Personnel and Guidance Journal, 2(1): 16-22.

Pennola, E., 2004. School refusal behaviour and depression. UES: City University.

Sekyere, E.A., 2012. Teachers' guide on topical issues for promotion and selection interviews and general professional update. Asuoyeboa, Kumasi: Afosek Educational Consult.

Trujillo, L.A., 2006. School truancy: A case study of a successful truancy reduction. Available from jjdp.law.ucdavis.edu/archives/vol-10-no1/Truancy.pdf [Accessed July 07, 2013].

Tuckman, B.W., 1994. Conducting educational research. 4th Edn., Florida: Harcourt Brace and Company.

Yelkpieri, D., 2016. Influence of parents' job and income on students' success in senior high school in the Awutu-Senya and Effutu educational Districts. A Paper Presented at International Conference on Education Development and Innovation at Tang Hotel, Accra.

\section{Bibliography}

Ademokoya, J.A., 2007. Truancy and the education of schoolchildren with hearing disability in Nigeria. African Journal of Educational Research, 11(1\&2): 95-100.

Truancy Prevention.org, 2012. Truancy prevention. Retrieved from www.truancyprevention.org [Accessed July 17, 2013]. 